My teeth were set on edge by reference to "the stable form of uranium", a violation of Kepler's second law in a description of how the Earth's orbit would change under various circumstances, and by "the rest mass of the neutrino is $4 \mathrm{eV}$ ".

Collins has been well served by his editor and publisher, but not perfectly. There are un-sort-out-able mismatches between text and index, references and figures; acronyms in the second half of the alphabet go undecoded; several well-known names are misspelled. And readers are informed that Weber's death occurred "on September 31, 2000". Well, Joe always said he could do things that other people couldn't, but there are limits.

Incidentally, my adviser was partly right: I should not have agreed to review this book. It is very much harder to hear harsh, sometimes false, things said about one's spouse after he can no longer defend himself. I am not alone in this feeling. Carvel Gold, widow of Thomas Gold, whose work was also far from universally accepted (see Nature 430, $415 ; 2004$ ), says the same thing.

Virginia Trimble is at the University of California, Irvine, California 92697-4575, USA. She and Joe Weber were married from 16 March 1972 until his death on 30 September 2000.

\title{
Watson's way with words
}

\section{The Writing Life of \\ James D. Watson \\ by Errol C. Friedberg \\ Cold Spring Harbor Laboratory Press: 2005. 193 pp. \$25, £18}

\section{Lewis Wolpert}

The Double Helix would on its own have established James Watson's reputation as a writer: it is the only book about science to appear in both the board's and the readers' lists of the Modern Library's top 100 nonfiction works. But Watson's textbooks have also given scientists, particularly students, a deeper understanding of genes and cells. And his popular-science books have given the public a new image of scientific research. The Writing Life of James D. Watson examines these achievements.

Watson was brought up to believe in the importance of books and reliable knowledge. He read widely and particularly enjoyed books by Graham Greene and Arrowsmith by Sinclair Lewis. Reading Erwin Schrödinger's What is Life? at the age of 17, Watson became convinced that genes were the essence of life and decided devote his own to their study. By the age of 25 he had, with Francis Crick, discovered the double-helix structure of DNA.

In relating this story in The Double Helix,

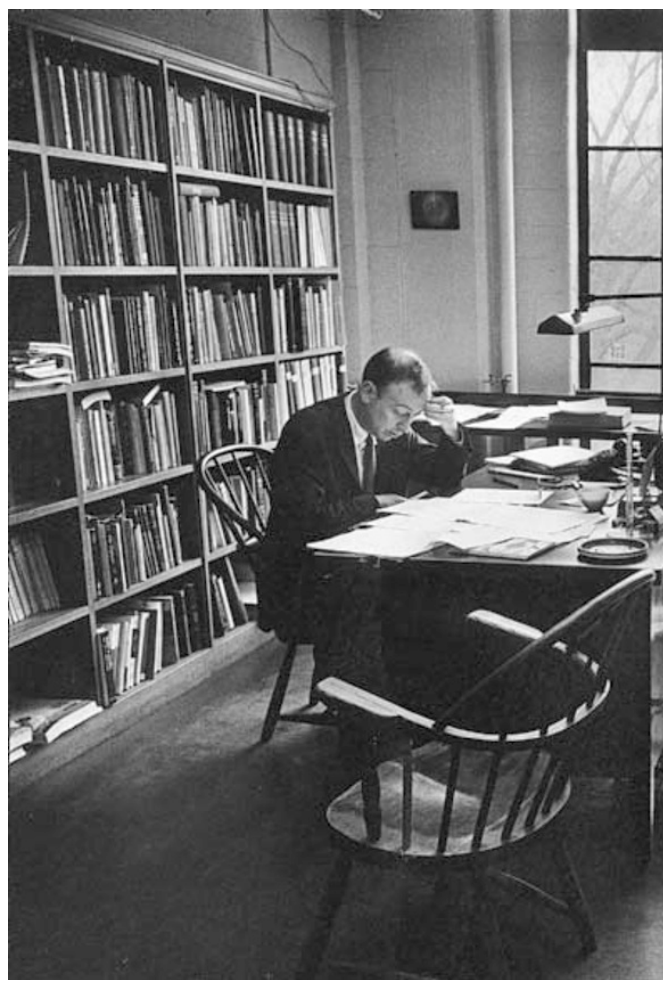

The write idea? In The Double Helix, James Watson gave a personal account of the quest for the structure of DNA.

Watson set out to produce a good story that the public would enjoy as much as The Great Gatsby. He started writing in 1962 with the working title "Honest Jim", which is illuminating in itself. The Writing Life of James D. Watson includes images of both the handwritten manuscript and the galley proofs. Indeed, almost half of Friedberg's book is devoted to photographs of text and letters, and of Watson and friends - they take up too much space, I think.

A draft of The Double Helix sent to Crick and Maurice Wilkins, a co-discoverer of the double helix, began: "I have never seen Francis Crick in a modest mood.” This upset them so much that they threatened legal action. Harvard University Press was due to publish the book, but concerns about its libellous potential, and Watson's refusal to change the text, caused them to withdraw, so Athenaeum Press published it instead. Watson was delighted that Lawrence Bragg agreed to write a foreword.

The great X-ray crystallographer J. D. Bernal could not put the book down, but thought it was particularly unfair to Rosalind Franklin. Initial reviews were mixed, but Peter Medawar wrote that "it will be an enormous success, and deserves to be so - a classic in the sense that it will go on being read." He was, as usual, right. Yet Crick found it difficult to take Watson's account seriously, although he did appreciate the quality of the writing.

Watson's skill as a writer is illustrated by this description of Rosalind Franklin. "Though her features were strong, she was not unattractive and might

even have been quite stunning had she taken even a mild interest in clothes. This she did not. There was never lipstick to contrast with her straight black hair, while at the age of thirty-one her dresses showed all the imagination of English bluestocking adolescents." Would that other scientists could write as well as that. Of his later memoir Genes, Girls and Gamow, some said that his style broke new ground with its postmodern innovatory syntax, but others were critical of both its literary style and its content. It is a pity that there are few examples of Watson's writing in Friedberg's book, nor any real analysis of the way he writes.

In all Watson's writing - from director's reports for the laboratory at Cold Spring Harbor to the popular-science books $A$ Passion for DNA and The DNA Story his strong character emerges: his sarcasm, criticism and praise make it clear what he thinks. His love of science and DNA always comes through, as does his contempt for his enemies. 


\section{Eastern promise}

\section{The Queen Anne churches in east London were precisely aligned on an east-west axis.}

\section{Heike Langenberg}

In 1714, Edmond Halley, professor of geometry at the University of Oxford, added the finishing touches to his latest paper, on "the variations of the magnetical compass" (Phil. Trans. R. Soc. Lond. 29, 165-168; 1714). Halley, best known today for the comet that bears his name, was interested in a wide range of fields, including astronomy, meteorology and geomagnetism.

Around the same time, the foundations of two new churches were laid in east London: Christ Church Spitalfields and St Anne's, Limehouse (right). Both buildings were aligned with remarkable precision on an east-west axis.

In a forthcoming paper in the Journal of the Society of Architectural Historians (64, 56-73; 2005), geologist Jason Ali and historian Peter Cunich suggest that Halley put his work on declinationcorrected compasses into practice in surveying the two churches. They argue that this may have been the first time that this modern science-based technique, which corrects for the difference between magnetic and true north, was used to align buildings.

Christ Church Spitalfields and St Anne's, Limehouse, were constructed under a programme established by two acts of parliament in 1711 and 1712 to build 50 churches in London's rapidly expanding East End. The programme was an attempt to fight irreligion and the rise of the dissenting churches in the poor suburbs.

The parliamentary acts were passed in the reign of Queen Anne when the Tory party was in power. It was in the Tories' interest to strengthen the Church of England because the parliamentary opposition party, the Whigs, were supported by religious dissenters. The buildings were specifically commissioned to be aligned in the traditional way along an east-west axis, emphasizing the link between the Anglican church and early Christianity.

In the end, only 12 churches were built, partly

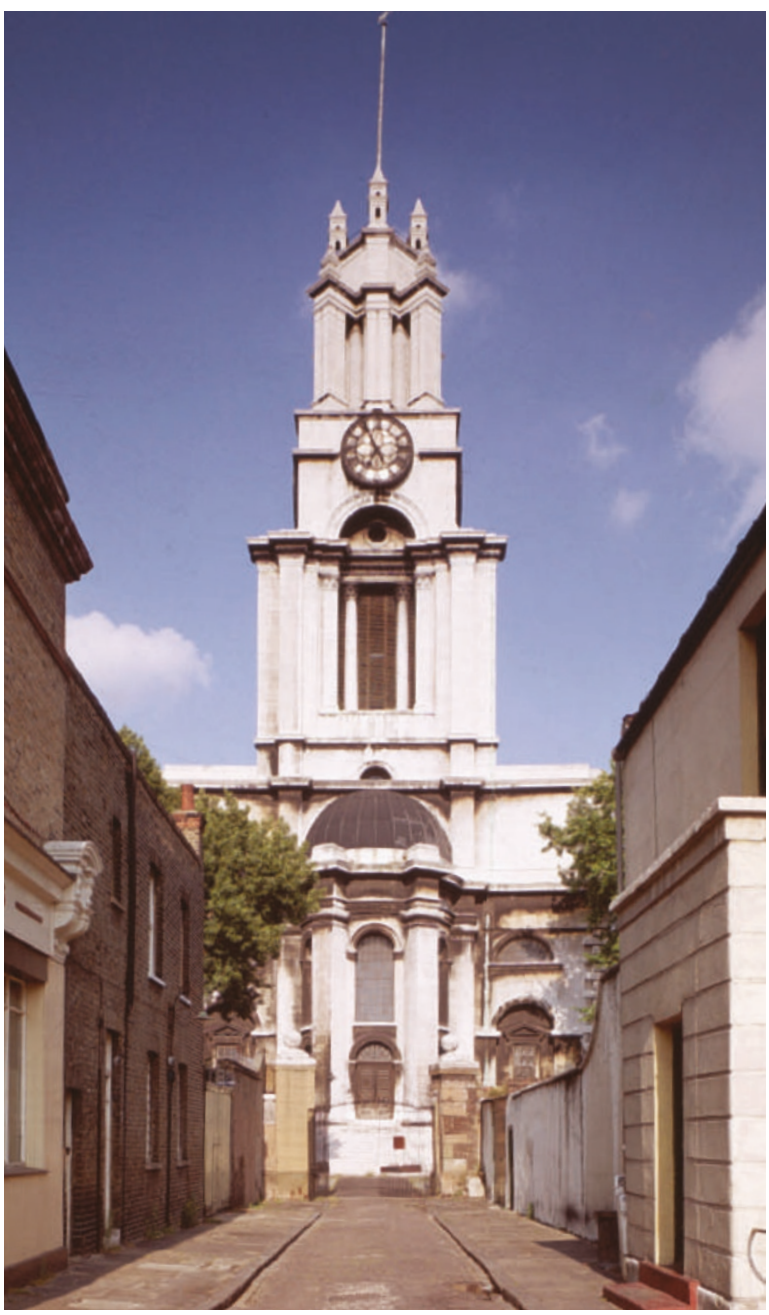

been achieved by using the position of the rising or setting sun on particular days: Easter, the feast day of the church's patron saint, or one of the equinoxes. But this approach cannot explain the precision in the alignment of Christ Church Spitalfields and St Anne's, Limehouse.

At London's latitude, the seasonal range of sunrise is quite large, from $51.5^{\circ}$ at the summer solstice to $128.5^{\circ}$ in mid-winter. Even a few days before or after the equinoxes, the sun rises and sets significantly away from a precise east-west axis. And by 1714 , the Julian calendar - still in use in England until 1752 - was out of synchrony with the seasons by 11 days.

Under the same parliamentary acts, Hawksmoor constructed four more churches whose axes are not oriented precisely east-west: St Alphege's in Greenwich, St George-in-the-East in Wapping, St George in Bloomsbury, and St Mary Woolnoth in the City of London. But each of these was built on a site with physical constraints that would have made attempts at correct orientation difficult. In the case of St-George-inthe-East, Hawksmoor had petitioned to knock down adjacent houses to open up the site, but without success.

Halley was active in the building commission in the summer of 1714 , attending meetings and visiting sites. The foundations for Christ Church Spi-

owing to financial constraints and partly because the political balance changed after the death of Queen Anne in 1714, when the Whigs became the dominant party.

The commission for building the new churches appointed Nicholas Hawksmoor as one of its architects. Hawksmoor had been a student of Halley's fellow Royal Society member Christopher Wren, who is most famous for designing St Paul's Cathedral. Halley and Hawksmoor had shared a circle of friends since the 1680 s.

Traditionally, the alignment of churches had talfields, and St Anne's, Limehouse, were laid during that summer. It seems extremely likely that Halley collaborated with Hawksmoor to assure their precise alignment with the help of his declination-corrected compass.

Ironically it has become difficult to determine the direction of east in some parts of London today. Magnetic noise, from the London Underground for example, can lead to significant local distortions of the geomagnetic field.

Heike Langenberg is a physical sciences editor at Nature.
Not content with overturning the public's view of science, Watson has also had a major influence on science textbooks. His Molecular Biology of the Gene established a new style for textbooks - using concepts as crossheads, for example — which has been much copied. Gavin Borden, publisher of the 63-volume James Joyce Archive, was keen to publish college biology textbooks and approached Watson. They began assembling authors, who gathered at Watson's home at
Martha's Vineyard in the summer of 1978, and Molecular Biology of the Cell was born. Experts who reviewed chapters were sure it was too difficult to be an undergraduate text, but Watson was convinced that it was just what was needed - and he was, of course, right. It is both beautiful and enormously successful.

The Writing Life of James D. Watson provides valuable insights into the process that led to this success. His contribution to solving the structure of DNA was highly significant, but if he and Crick had not worked out the structure, Franklin and Aaron Klug would have done so soon afterwards. Watson himself regards his writing, which could not have been done by anyone else, as an even greater achievement than his work on DNA that led to a Nobel prize.

Lewis Wolpert is at the Anatomy Building, University College London, Gower Street,

London WC1E 6BT, UK. 